\title{
A grassroots view from the streets and jungle
}

What about the people on the streets and in the jungles? Maybe we should ask the famous Phantom to help us establish a jungle wire service. I'm willing to assist.

\section{By JOSEPH KA'AU}

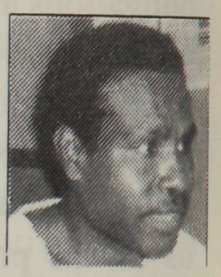

I'M PRESENTING a view about the media from the streets, the jungles, the rivers and the seas of Papua New Guinea. It is indeed a privilege to be seated with some people who have made a big contribution to the development of our country to ensure that our country is free.

But first an observation: It seems that the media - or at least the organisers of the Media Freedom seminar - have indicated their priority in terms of where their interest is. With due respect and no malice intended, first it is the government/politician. Then big business. Last of all come the grassroots people and workers. I would like to believe that is not the case.

I also spoke at the recent seminar organised by the Constitutional Review Commission. Again it was the same order - government first, big business second and the people last. Surely it must be coincidence.

I have a limited experience in the news media, mainly the print media. But for the last six years I have been involved in addressing community development and social justice issues in the country, working with non-government organisations and people. And with the people that I am working with, we have identified the media as an important tool and ally to assist us in addressing these issues. Off course, people in the public and private sector will say they have similar objectives.

The role of the news media is that of a messenger - delivering a message. It is also maybe knowing why they are delivering such a message and knowing also the possible consequences on all who come in contact with the message. 


\section{PNG MEDIA DEBATE}

The media tells the story as it was told by a witness, participant or the messenger him/herself.

So the question arises, in telling the story or delivering the message, who is the messenger accountable to for the consequences? Here are some possible answers: To the source of the message, to him/herself, to the recipient, to somebody else ... and nowadays to the owner of the medium by which the message is being delivered.

In our country we are limited to a few big (our standards) newspapers, a handful of national radio stations, the television, and with a few regional, provincial media outlets. Ownership is varied too. So the question of accountability is also varied.

I worked for a newspaper that endeavoured through its publications to bring about changes for the better to the country, and maybe the region. Seeking to improve the lot of the masses. An honourable endeavour indeed.

As a social justice worker, that is what I want to see as a role for the media. And so if you are going to ask me who the media should be accountable to ... my answer is obvious: To the people of this country. But not to a lesser privileged group or individual, as some members of Parliament would like to think.

I would like to believe that for what it is doing the media should be accountable to this country. But I know that maybe the belief is just a good dream.

Recently I wrote a critique of the Pacific Islands News Association, basically saying that for PINA members (mainly media owners and journalists) to report fairly about the masses in the region, they must be of the region. Not people whose experience of the Pacific is hire cars, hotel rooms and fat expense accounts and reporting most of their time from overseas destinations. I do not have to tell you why these people write.

You cannot write properly about the streets and the jungles of Papua New Guinea unless you are of the streets or jungles yourself. How many of us from the famed world of journalism or media can raise our hands and say: 'Yes, I used to collect bottles in Port Moresby to feed, clothe and educate myself.' And how many more of us can say: 'Yes, I have walked three days to a first aid post only to find there was no medicine. And then desperately spending more days to find remedies for my illness.'

I don't think I can count enough on one hand. When are we going to get out of our air-conditioned offices and comfortable chairs.

Journalism should add another phrase to its vocabulary - 'fax and telephone journalism'. Only government and big business have these facilities. What about the people on the streets and in the jungles? Maybe we should as 


\section{JOSEPH KA'AU}

the famous Phantom to help us establish a jungle wire service. I'm willing to assist.

I know that it isn't cheap to run a media outlet. It costs money. Therefore, I think that for any media outlet to exist, costs must be met and a moderate profit made where possible. Some media exist for the profit only. Where does the interest of our people come in.

In my view, most media outlets exist not to serve the little people at all. Dissemination of information to improve the living standards of the masses is not their business. Other things are priority.

I would even go so far as to suggest that maybe most media outlets in this country fall under this category. I know that many in this room will vehemently oppose such suggestions. They have their rights.

In conclusion, I would like to by cite a few experiences which may make us ask questions about the media's interests and, in my view, media control by government and big business.

In 1992, I was at the Kutubu oilfields when the construction of the pipeline was temporarily halted by angry local landowners. The reason for their blockade, I was told, was that the company had made promises for certain services to be delivered on a certain day. The day had passed without those services being delivered.

I filed a story - in fact, a couple of stories - for a newspaper with exclusive photographs. One story was run. The next day I was told that the industry was furious. The other stories did not see the light of day. Whether the industry being furious had anything to so with it, I do not now. But I recall the editor telling the industry to 'go jump'.

Now more problems are emerging at Kutubu. Sosoro Hewago is rightfully asking for his share now. I would suggest that ask for his cut, maybe 10 per cent from Chevron and another 10 per cent from British Petroleum. The initial dissatisfaction was expressed way back in 1992. Surely there must be parallels.

Last year, BHP helped the government of Papua New Guinea draw up legislation to effectively stop our people from exercising their basic democratic right to claim fair compensation for environment damage. In my view, that legislation also effectively indicated that Papua New Guinean judges cannot be relied on to make fair and sound judgements on such claims - now a non-issue.

Last December, a national doctor claimed on a television program that a person living along the Lagaip/Strickland river had died from possible chemical poisoning. The program showed also that PJV was probably discharging more heavy metals into the river system than allowable and that it had no compliance criteria for mercury, a highly toxic chemical once into the food chain. What are we waiting for? Ten more people to die? One hundred more to people to die? 
You tell me. Two months later, zero news media interest.

I was a gate crasher at one Press Club event at the Islander hotel some years back. Lawyer Loani Henao was the keynote speaker. Henao said then that the media were too lenient today. They have got softer. Ithink they have got deeper into bed with government and big business and have forgotten the small people.

Get out of your marriage with. such characters and hear the cries of your people from the streets, the jungles, the mountains, the rivers and the islands of Papua New Guinea.

$\square$ Joseph Ka'au is a former journalist and editor of Wantok Niuspepa. Now he is an environmental campaigner and village activist in the Gulf, and he has been the PNG representative of Greenpeace Pacific.

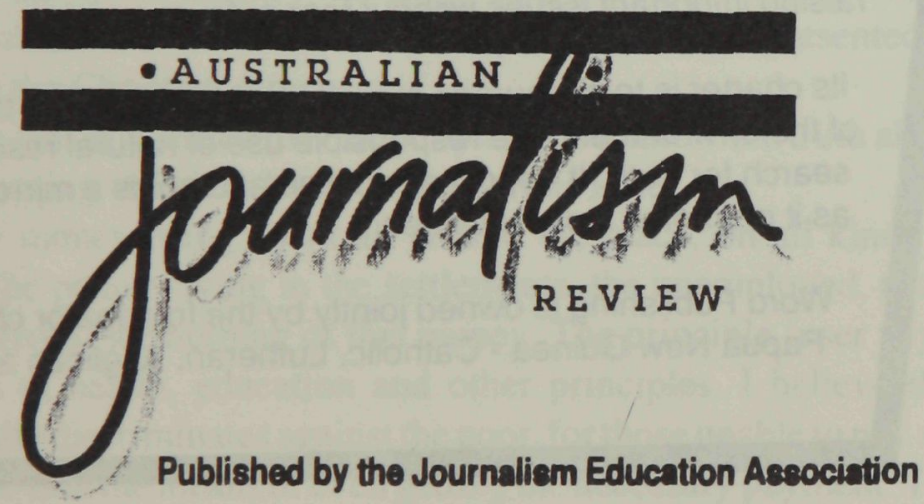

All subscriptions must be prepaid:

Institutional subscriptions: $A$ SAO per year

Individual subscriptions: A\$20

Available from:

School of Communication and Cultural Studiee, Curtin University, GPO Box U1987, Perth, Western Australia.

Tel: (619) 3517621 Fax: (619) 3517726 